\title{
Factors Driving Electronic Commerce Initiative in Malaysian' Organization
}

\author{
Ali Khatibi', Ahasanul Haque ${ }^{2}$, Hishamuddin Ismail ${ }^{3}$ and Shameem Al Mahmud ${ }^{4}$ \\ 1. School of Business and Management, University College Technology \& Management, Malaysia \\ E-mail: alik101@yahoo.com \\ 2. Department of Business Administration, International Islamic University Malaysia 53100 \\ Kuala Lumpur Malaysia \\ 3. Faculty of Business and Law, Multimedia University, Melaka, Malaysia \\ E-mail: hisham@mmu.edu.my \\ Fax: +603-61964850,E-mail:ahasanul@iiu.edu.my \\ 4. Faculty of Management, Multimedia University Cyberjaya, Malaysia \\ E-mail: shameemerry@yahoo.com
}

KEY WORDS E-marketing; online competitiveness; e-strategy; CRM; B2B and B2C

\begin{abstract}
This study is trying to investigate major factors driving e-commerce adoption, and assess the organizational readiness for Malaysian companies operating in FIZ (Free Industrial Zone) in the state of Penang and Kedah. This study used structured questionnaires and a purposive judgmental sampling method in getting responses from IT managers or decision-makers on e-commerce initiative. Dependent variable is the organization readiness level in adopting e-commerce strategy and independent variables are online competitiveness, customer relationship management and value chain management. This study shows that Malaysian companies are lagging in e-commerce initiative compared to American companies, but Malaysian companies are on par with European and East Asian companies. It reflects the general views that e-commerce is "American Originated" technology and American companies have an edge in adopting this new and enabling technology to enhance their global competitiveness. The Malaysian companies have been proactively evaluating and embarking on IT projects to enhance their international competitiveness and they are on par with European and East Asian companies in e-commerce initiative. This study shows Online Competitiveness, Customer Relationship Management and Value Chain Management are affecting decision on ecommerce initiative. The results of this research will also serve as an initial feedback to Malaysian authorities to step up their efforts in promoting IT awareness, and adopting new and enabling technologies in Malaysian companies. It is also hoped that this study can provide a guideline for Malaysian companies in evaluating and formulating effective strategies and policies into e-commerce in this information age.
\end{abstract}

\section{INTRODUCTION}

Consider what tasks the company has to perform when an employee wants to buy something, for example, a filing cabinet. First the employee generates a request for the filing cabinet, including some specifications (four drawer vs five-drawer, with lock vs no lock), and passes this request on through an approval process involving one or more managers, depending on the cost. That request finally makes it over to the purchasing department, where someone has to check through the office supply catalogs to select an appropriate model

Corresposdent Author Address:

Dr. Ahasanul Haque, Department of Business Administration, International Islamic University

Malaysia, 53100 Kuala-Lumpur, Malaysia.

Fax: +603-61964850,

E-mail: ahasanul@iiu.edu.my and supplier. Assume the company doesn't have a single preferred supplier for office supplies, so the purchasing agent has to check more than one catalog and call the suppliers to determine the availability of the filing cabinet. Once the supplier is selected, the agent can issue a purchase order, and either fax or mail it to supplier.

Once the order has been received, the supplier verifies the credit and sales history of the ordering company, checks the warehouse for inventory, and finds out when shipper can pick up the cabinet from the warehouse and deliver it to the appropriate location. Satisfied with the item can be delivered within the time requested, the supplier creates a shipping order, notifies the warehouse, and creates an invoices for the filing cabinet. The invoice gets mailed, the filing cabinet gets delivered, and somewhere along the way, your company pays the bill for the cabinet. 
Now consider how this might have been done using electronic commerce. The employee would visit the Web site of either the distributor or the manufacturer, and select the appropriate filing cabinet by matching the needs (colour, number of drawer, lock, size) with the data in an online catalog. The employee would then use electronic mail to send a digital request (perhaps appending the Web page of the selected product) to the manager for approval. Once approved, the manager would simply use e-mail to forward the request to purchasing. Purchasing could then copy the necessary information into their order database, and send an electronic order to the supplier, via EDI or other form, also using e-mail.

When the supplier receives the order, a computer program might automatically insert the order into a database of pending orders, check inventory at the warehouse, check your company's credit status, and earmark the item for delivery. The same program might then pass a shipping order electronically to appropriate warehouse and create an invoice. If a shipping agent is used, the warehouse would notify the shipper via e-mail. Once the filing cabinet was received, accounts payable would instruct the bank, via e-mail, to transfer the appropriate funds to the supplier.

With electronic commerce, everything starts out and stays digital; only different applications are needed to transfer and process the data as it winds its way through the order process. Imagine how much more efficient this process would be if you were able to obtain all the information you needed right at your fingertips, and also make your purchases, all using one medium.

\section{Research Problem}

The decision makers particularly the chief executive officers and chief financial officers in most organizations have difficulty in evaluating and adopting e-commerce strategy. In today's 'Networked Economy', where individuals and companies worldwide are being electronically linked, business rules keep changing and companies have to respond fast to changes to survive. Marketplace is changing every second at an increasing pace. E-commerce is increasingly crucial to business success, but implementing it successfully requires a broad understanding of technology, law, policy, and business processes. There are many factors affecting decision-making in adopting of E-commerce, the decision is complicated by the pace the Internet changes the business rules in the globalization age.

\section{Research Objectives}

Research in e-commerce in Malaysia is very limited and not widely published. This research is intended to study e-commerce initiatives for manufacturing companies operating in Free Industrial Zone (FIZ) in the state of Kedah and Penang. Specifically, the study is intended:

To investigate whether Malaysian companies are lagging in adopting e-commerce strategy compared to American, European and East Asian companies.

To study major factors driving decision making to adopt e-commerce strategy.

\section{Literature Review}

There are a variety of definitions of "electronic commerce" (e-commerce) in the literature. It has been defined as a combination of technologies Electronic Commerce World Institute (1996), as a business methodology Kalakota et al. (1996) and as business over networks and computers Haynes (1995).

Oracle Inc. defines e-commerce as a dynamic set of technologies, applications, and business processes that link enterprises, consumers, and communities through electronic transactions and the electronic exchange of goods, services and information Internet Commerce (1999).

For some time now, large business enterprises have used electronic commerce to conduct their business-to-business transactions. Electronic data interchange (EDI) on private networks began in the 1960s, and banks have been using dedicated networks for electronic fund transfer (EFT) almost as long. Recently, however, with the increased awareness and popularity of the Internet, electronic commerce has come to encompass individual consumers as well as business of all sizes Kosiur (1997).

The Internet is already changing the way that many companies conduct their business. As that influence grows, and more companies use the Internet, the possibilities for conducting business-to-business commerce on the Internet will expand greatly, and become more of a routine part of commerce than it is today.

To many, electronic commerce is defined as the buying and selling of products and services 
over the Internet, but there are many more aspects to it. From its inception, electronic commerce has included the handling of purchase transactions and funds transfers over computer networks. It is now grown to include the buying and selling of new commodities such as electronic information.

Over the past few years, both the press and business community have increased their focus on electronic commerce involving the consumer. Meanwhile business-to-business electronic commerce is rolling along, stronger than even ever. The Internet has also given business-tobusiness electronic commerce a boost - in some cases, smaller companies are now discovering that they can conduct business on line, just like their larger counterparts. And business of all sizes are finding that they can take advantage of the Internet to lower cost of electronic commerce either by replacing other networks, or by using the Internet.

The move for business to digitize information isn't new - it's been going on for more than a decade, and continue to increase as personal computers become standard business equipment for more and more corporations. What is making a notable difference to businesses is that a significant synergy has formed between the use of digital information, computerized business practices, and the Internet. This synergy is what enables electronic commerce.

\section{Forces Driving/ Enabling E-Commerce}

A study conducted by Anderson Consulting (1999) shows that there are four forces, as depicted in Figure 1, which drives or enables ecommerce, namely, business value, technology infrastructure, customer value and cooperative regulatory environment. Anderson Consulting predicts the electronic economy will overtake the traditional industrial economy by year 2003 Anderson Consulting (1999).

A reasonably favorable deregulatory environment increases the competitive tempo, which encourages businesses to seek means to obtain or retain a competitive advantage. Technology offers businesses new opportunities to enhance value to its customers, increase its efficiency and extend its reach. Consumers respond to the increased value by favoring these leading businesses. Thus rewarded, these businesses reward the technology providers with

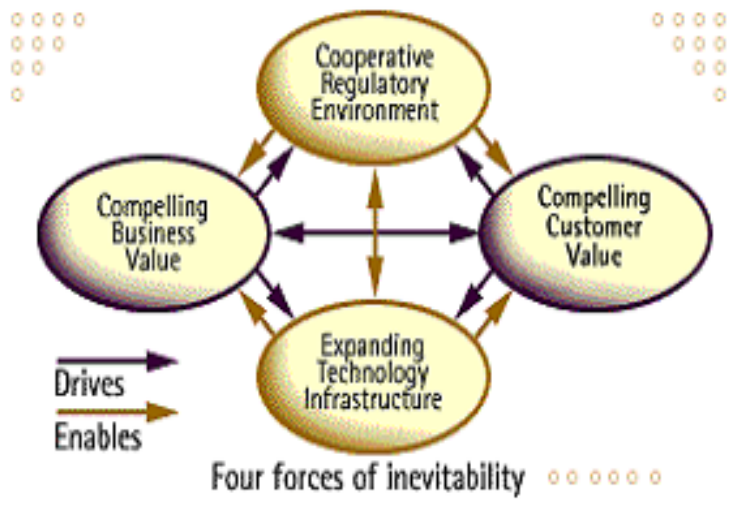

Fig. 1. Four forces of inevitability

Source: What is eCommerce? "eEnterprises conducte Commerce in the eEconomy" http://www.ac.com/ ecommerce/ecom_what_is.html

additional purchases. Consumers also favor governments trade liberalization, which has permitted and encouraged new value streams. Each circle of activity has been reinforcing the others Anderson Consulting (1999).

In another study, conducted by a management consulting firm A.T. Kearney, sought the views of CEOs and senior business executives at 213 companies in 11 industries in more than 20 countries. The study shows nine out of 10 cited information technology (IT) as critical in every way or very important for their businesses' future success. One-third cited the use of new technologies as the top critical success factor for the future. 58\% identified loss of competitive advantage as the main consequence of not keeping pace with IT Saia (1999). Information technology and Internet linkage are widely seen as the catalyst to propel the electronic commerce into every aspects of domestic and international trade.

\section{Online Competitiveness}

Whether leading the charge or tagging along one step at a time, companies today are moving inevitably towards a new commercial world order. Fundamental methods by which business is conducted will be forever changed as organizations use technology to link enterprises, consumers, and communities through electronic transactions and the electronic exchange of goods, services and information. "The Internet 
economy will have the same impact on society that the industrial revolution had 300 years ago", says John Chambers, the CEO of Cisco Systems Internet Commerce, (1999).

In e-Commerce, coordination can be achieved virtually, at low cost. Whole supply chains can be forged quickly and connected through desktops. And whether the seller is really in Boston, its "warehouse" a totally different company in Topeka, and the payment processor still another firm in Bangladesh are considerations largely irrelevant to consumers as long as their expectations for quality, price and service are met. Melnicoff (1999)

Porter (1994) reported efficiencies generated by online commercial efforts on marketing on Web results in "10 times as many units [sold] with $1 / 10$ the advertising budget". It is about one-fourth less costly to perform direct marketing through the Net than through conventional channels Verity and Carey (1994). This fact becomes especially critical in the face of shortening technology and product life cycles and increasing technological complexity in the business arena of the globalization age. Using SunSolve Online, Sun Microsystems has save over US\$ 4 millions in Frequently Asked Questions (FAQs), since Sun "reengineered information processing around the WWW" Neece (1995).

Web sites are available on demand twentyfour hours a day. The interactive nature of the Internet can be used by marketers to hold the attention of the customer by engaging him or her in an asynchronous "dialogue" that occurs at both parties' convenience. This capability of the medium offers unprecedented opportunities to tailor communications precisely to individual customers, allowing them to request as much information as desired. Further, it allows the marketer to obtain relevant information from customers for the purpose of serving them more effectively in the future.

\section{Value Chain Management}

Communications and information technologies often make it more effective and less expensive to collaborate with outsiders than to own all the resources associated with your business. Although coordination and day-to-day control might be a little more difficult, organizations more than make up for the difficulty in quality, flexibility and cost. The result is that specialists are cropping up in practically every major business activity, from product design to delivery, and it's now possible to pull together a virtual organization that employs only "best-ofbreed," cost-effective contributors at each points Melnicoff (1999).

Banks, consumer-packaged-goods companies, insurance providers, educational institutions, manufacturing firms, and health care providers are cutting the value chain and enhancing business relationship by utilizing the Internet and its offshoots, intranets and extranets Internet Commerce, (1999).

Clearly, it is important for organization to focus on the part of the value chain most valued by customers and team up with the best for the rest. Specialized niche players or smarter, faster competitors will attack any weak parts of your value proposition and marketing position. If you're not the absolute best at performing a function that can be bought elsewhere, don't do it. Melnicoff (1999).

In the business-to-business arena, ecommerce strategies allow businesses to leverage electronic alliances to speed up the delivery of products and services to market. Companies set up electronic linkages to work more closely with their suppliers and save millions of dollars in inventory and distribution costs.

Internet-based procurement solutions leverage the Internet as a business and technology enabler, using workflow-driven process automation and supply-chain collaboration to streamline purchasing and reconcile payments. The procurement personnel can be deployed strategically for analysis and sourcing. By automating the generally paperbased procurement of maintenance supplies, office supplies, equipment, services, and the like, companies can realize substantial cost savings Internet Commerce (1999)

\section{Customer Relationship Management}

In order to be successful in the market-driven economy, customer satisfaction is the top priority for all organization. With greater reach of information through proliferation of Internet, global marketplace offers customers with unlimited choices of products and services. Customers demand instant access to product information, e.g. features and pricing, ease in 
ordering products and choices of payment methods.

Customers and suppliers who have embarked on e-commerce initiatives are beginning to demand their business partners to jump on their bandwagon to further streamline their business processes. In certain case, it has become mandatory for company to adopt and draw up a plan to embrace e-commerce in order to continue their business dealings or partnership.

Cisco has become a world leader in Internet commerce by winning customers with streamlined, self-service business processes. Unassisted Web sales account for roughly 73 percent of Cisco's $\$ 8.3$ billion per year in orders. Customers and business partners also have direct access to technical support and order status information, saving Cisco $\$ 550$ million annually while improving customer satisfaction Internet Commerce (1999).

Customer motivations can be examined in categories of benefits, rewards and relationships. Customer values can be examined in terms of an individual's value assessment of risk and benefit, particularly as those values relate to the use of electronic commerce technologies.

Bitner (1995) describes an encounter between a business and a customer and the associated relationship building around the concept of "promises". Bitner poses three components of promises: making promises; enabling promises; and keeping promises. The three components of promises translate roughly to the marketing, advertising, and sales functions; the electronic servicescape for direct customer interaction; and the fulfillment process and supporting infrastructure. Electronic commerce offers the opportunity for an entire transaction process advertising, purchasing decision, and order fulfillment - to occur within one customer interaction at the electronic servicescape.

Stone (1994) describes "relationship marketing" not only as a benefit to a direct marketing industry company, but as a necessary condition to profitability. Stone recognizes that the first sale to a direct marketing customer is not profitable when considering all of the costs associated with obtaining that customer. Given that investment in obtaining a new customer, it is logical and essential to develop and maintain a long-term mutually beneficial relationship with that customer that results in repeat sales. This is the business rationale behind the practice of database marketing.
This recognition of relationships as a necessary foundation for profitability in an industry that has direct contact with individual customers is one of the reasons the catalog industry is considered a precursor of electronic commerce is because they have been doing this over the last two decades.

Electronic collaboration is the most important part of the business-to-business electronic relationships - two companies leveraging each other's information systems to enhance the overall customer experience. Thanks to the tight electronic links enabled by the Internet, global express-delivery company United Parcel Service (UPS) provides most of the shipping for the world's largest PC manufacturers. UPS is adding value to the business transactions to each of the major customers Internet Commerce (1999).

Once customers configure their orders for computers and peripherals, UPS and its partners coordinate the shipping activities for multiple locations, drastically reducing the manufacturers' inventory carrying costs and ensuring that all pertinent packages arrive at the customer's location on the same day. Customers can track their shipments through the UPS delivery network, using a single order number. Far beyond providing mere transportation services, UPS is a trusted partner, enabling these companies to offer more efficient routing, and fulfillment services all of which lead to greater customer satisfaction Internet Commerce (1999).

The focus on customer relationships and the evolutionary approach described by these organizations is in contrast to much of the hype surrounding the Internet and World Wide Web which suggests some kind of revolution in the making through radical new approaches to commerce Wanninger (1996 and 1997).

\section{RESEARCH METHODOLOGY}

E-commerce (electronic commerce) solutions bring the open standards and universal access of the Internet to the core business processes of buying and selling goods and services. This is a great promise for a lot of companies to jump start into E-commerce, but generally a lot of companies are relatively cautious in adopting E-commerce initiatives. Some pioneers, for example Amazon.com, who has been operating online retailing business for sometime are still struggling to make the company a profitable one, but others 
like example Cisco is doing wonders with their Ecommerce efforts.

E-commerce is being adopted by many organizations in their business model, which emphasizes speed, efficiency and customer relationship. Studies on critical success factors for numerous organizations shows online competitiveness, customer relationship management, and value chain management are becoming driving factors in today's competitive marketplace. Therefore, online competitiveness, customer relationship management, and value chain management would influence in ecommerce initiative. Organization's internal factor, such as the organizational setting is another factor that may impact the e-commerce implementation. Organizations need to have an appropriate culture and setting to adopt e-commerce successfully. Figure 2 provides a graphical representation of the conceptual theoretical framework.

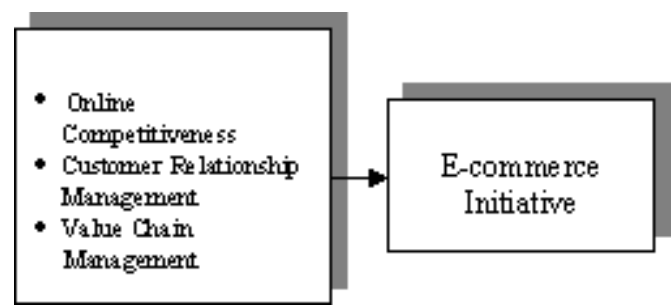

Fig. 2. Conceptual model of driving forces in commerce initiative

\section{Hypothesis}

Malaysia attracts large numbers of foreign investments in the manufacturing sector, primarily in the electrical and electronics industry, which is the top export earner. The value of electrical and electronic products grew by $22 \%$ in 1999 to RM 185.3 billion, and accounted for $57.7 \%$ of all exports from Malaysia (The Star, 5-Feb-2000). In the globalization age, Malaysian companies need to be well equipped with enabling technologies to be competitive in the open marketplace.

The small and medium industries (SMI's), which are providing products and services to the multi nation corporations (MNC's), will continue to the centre of growth for Malaysian based companies. Due to better IT infrastructure and exposure in their homeland, MNC's are generally thought to be the forerunner on ecommerce initiative. In the quest to streamline their business processes, MNC's will be slowly imposing e-commerce requirements on SMI's for continual business transactions.

Hypothesis 1 is intended to study the differences in e-commerce readiness level between companies of various equity holding, this is to test if Malaysian companies are lagging in e-commerce readiness.

Hypothesis 1: Equity holding structure is influencing decision of electronic commerce initiative.

Online competitiveness, value chain and customer relationship management are being pursued by many organizations to be their core values in their business processes. Most other literatures also put forward business models, which include these elements. Hypothesis 2 is intended to test impact of these variables in affecting decisions on e-commerce adoption.

Hypothesis 2: Online competitiveness, customer relationship management and value chain management are influencing decision of electronic commerce initiative.

\section{Data Collection and Measurement}

The target population for this study consists of manufacturing firms located in Free Industrial Zone in the state of Penang and Kedah. From the Penang Development Guide, it was estimated that the manufacturing population would be about 300 companies. Sources from Perbadanan Kemajuan Negeri Kedah (PKNK) indicated there were about 150 companies operating in Industrial Zone in Sungai Petani and Kulim.

This study required that the sample to have Internet connectivity and other IT infrastructure setup, with appropriate understanding and exposure to Internet transaction functionalities and capabilities. Given the situation, the probabilistic method of sampling would not have achieved the level of accuracy and confidence desired in this study. As such, the purposive judgmental sampling method was used in the sampling design.

Data collection was primarily done by personal delivery and mail. A number of sampled companies selected were contacted to identify individuals to answer the questionnaire, others are addressed to the IS manager of the company. The respondents for this study were the decision makers or IT personnel influencing decision making in investment in computerization 
projects. A self-addressed, stamped envelope was included to facilitate the return of the completed questionnaire. Some of the questionnaires were distributed by IT vendors, who knew their clients well and were in regular contact with them, and the return rate were expected to be higher.

The questionnaire was sub-divided into several sections. Section A consisted of 7 general questions, where respondents were requested to provide some general information pertaining to individual and organization profile. Section B has 4 questions that are intended to reveal more information about respondents' IT infrastructure setup. Section C has 17 questions correspond to Online Competitiveness, Customer Relationship Management, Value Chain Management. Each item in section $\mathrm{C}$ was measured on a 6-point Likert scale anchored by 1 (Strongly Disagree) and 6 (Strongly Agree), with the response of 6 indicating the element strongly influencing e-commerce initiative.

In order to ensure the reliability of the measures, the multiple statements on Online Competitiveness, Customer Relationship Management and Value Chain Management were assessed with Cronbach's Alpha reliability test. The alpha value ranges from 0.73 to 0.88 . The values of Cronbach Alpha indicates high reliability of measurement for all the independent variables. Table 1 shows the alpha value for all variable grouping.

\section{RESULTS}

A total of 220 questionnaires were distributed through mail, MBA course-mates and IT vendors,
Table 1: Cronbach's alpha value for variable grouping

\begin{tabular}{lcc}
\hline Variable & No. of Items & $\begin{array}{c}\text { Cronbach's } \\
\text { Alpha }\end{array}$ \\
\hline $\begin{array}{l}\text { Online } \\
\text { Competitiveness }\end{array}$ & 7 & 0.8766 \\
$\begin{array}{c}\text { Customer } \\
\text { Relationship } \\
\text { Management }\end{array}$ & 5 & 0.8116 \\
$\begin{array}{l}\text { Value Chain } \\
\text { Management }\end{array}$ & 5 & 0.7313 \\
\hline
\end{tabular}

only 115 were collected from respondents in this survey. Of the 115 received, only 85 are usable for the purpose of this study. The response rate was approximately $52 \%$, while the overall response rate was about $39 \%$. Table 2 shows the profile of the sample.

Of the 85 respondents, nine were Managing Directors, seven were Directors, twenty four were Department Managers, while forty-five Section Managers make up 53\% of the respondents. As for the organization profile, 32 companies have less than 300 employees, while 27 companies have between 301-2000 employees and 26 companies have more than 2000 employees. On the equity holdings of the responding organizations, the majority of companies, $67 \%$ or 57 companies were foreign owned. Of the 57 foreign owned companies, 41 companies are USA-based, while East Asia (Japan, Taiwan and Korea) and Europe have 9 and 7 respectively.

IT awareness for the responding companies were relatively high, with 39 companies having high awareness level, 39 companies with medium awareness, and only 7 companies having low awareness.

Table 2: Respondent/organization profile

\begin{tabular}{|c|c|c|c|}
\hline Profile & Description & Number & $\%$ \\
\hline \multirow[t]{4}{*}{ Designation } & Managing Director & 9 & 10.6 \\
\hline & Director & 7 & 8.2 \\
\hline & Department Manager & 24 & 28.2 \\
\hline & Section Manager & 45 & 53 \\
\hline No. of & Less than 300 & 32 & 37.6 \\
\hline \multirow[t]{2}{*}{ Employees } & Between 301 to 2000 & 27 & 31.8 \\
\hline & More than 2000 & & \\
\hline \multirow[t]{4}{*}{ Equity Structure } & USA & 41 & 48.2 \\
\hline & Japan, Taiwan, Korean & & \\
\hline & Europe & 9 & 10.6 \\
\hline & Malaysia & 7 & 8.2 \\
\hline \multirow[t]{3}{*}{ IT Awareness } & Low & 7 & 8.2 \\
\hline & Medium & 39 & 45.9 \\
\hline & High & 39 & 45.9 \\
\hline
\end{tabular}




\section{E-Commerce Readiness Profile}

There were five levels of e-commerce readiness being measured in this study, $47.1 \%$ of the responding companies were already using ecommerce to perform business transactions, $10.6 \%$ has plans to start e-commerce in the next six months, $14.1 \%$ planned to implement ecommerce between six to twelve months, $20.0 \%$ may adopt e-commerce in more than twelve months, while $8.2 \%$ or seven companies has no plan in place for e-commerce (Table 3 ).

The descriptive analysis in table 4 shows that the mean for all the three variables Online Competitiveness, Customer Realtionship and Value Chain Management is high. This further strenghtens our postulation that these three variables strongly influences the e-commerce readiness.

Table 3: E-commerce readiness profile

\begin{tabular}{llrc}
\hline $\begin{array}{l}\text { Profile } \\
\text { E-commerce } \\
\text { readiness }\end{array}$ & Description & Number & $\%$ \\
\hline 5 & Already in place & 40 & 47.1 \\
4 & In the next 6 months & 9 & 10.6 \\
3 & Btw 6 to 12 months & 12 & 14.1 \\
2 & More than 12 months & 17 & 20 \\
1 & No plan as yet & 7 & 8.2 \\
\hline
\end{tabular}

Table 4: Descriptive statistics of the composite variable

\begin{tabular}{|c|c|c|}
\hline Variable & $\begin{array}{c}\text { Mean } \\
n\end{array}$ & $\begin{array}{c}\text { Std } \\
\text { Deviation } \\
n\end{array}$ \\
\hline Online Competitiveness & 4.69 & 0.78 \\
\hline Customer Relationship & 4.72 & 0.74 \\
\hline Management & 4.37 & 0.73 \\
\hline
\end{tabular}

Table 5: Mean rank result by equity structure

\begin{tabular}{lrr}
\hline & $N$ & Mean Rank \\
\hline E-commerce Readiness & \multicolumn{3}{c}{} \\
USA & 41 & 51.28 \\
East Asia & 9 & 36.33 \\
Europe & 7 & 37.64 \\
Malaysia & 28 & 34.43 \\
\hline Total & 85 & \\
\hline Chi Square & \multicolumn{3}{|}{11.072} \\
Df & \multicolumn{3}{c}{3} \\
Asymp. Sig. & \multicolumn{3}{c}{0.011} \\
\hline
\end{tabular}

\section{Influence of Equity Holding Structure On Electronic Commerce Initiative}

Results of the test of differences (Kruskal-Wallis One-Way ANOVA) is shown in Table 5. The test is significant which indicates that equity holding is influencing decisions on e-commerce initiatives. From the mean ranking we can see that the USA based companies are much much e-commerce ready compared the the other three regions.

Influence of Online Competitiveness, Customer Relationship Management and Value Chain Management on Electronic Commerce Initiative

For multiple discriminant analysis, the ecommerce readiness levels were separated into three groups, namely group 1 (No plan as yet), group 2 (In the next 6 months, Btw 6 to 12 months and More than 12 months), and group 3 (Already in place). Group 1 has 7 companies, group 2 has 38 companies, and group 3 has 40 companies.

For the discriminant analysis the sample was divided into two portions, with the first group called the cases selected (used for estimation) and the second group called the holdout sample (used for predictive accuracy). This is done to test the internal validity of the model and assessment of its predictive accuracy.

As can be seen in Table 6 and 7 the predictive accuracy of the model is $75.41 \%$ and $75 \%$ respectively. What can be concluded here is that by using the three variables of online competitiveness, customer relationship management and value chain management we can classify the respondents according to their e-commerce readiness.

To test further whether the model is good three tests were conducted as depicted in Table 8 , the hit ratio exceeds both the maximum

Table 6: Hit ratio for cases selected in the analysis

\begin{tabular}{lccrrr}
\hline $\begin{array}{l}\text { Actual Group } \\
\text { Group }\end{array}$ & Cat. & \multirow{2}{*}{$\begin{array}{c}\text { N. of } \\
\text { Cases }\end{array}$} & \multicolumn{3}{c}{$\begin{array}{c}\text { Predicted } \\
\text { Membership }\end{array}$} \\
\cline { 3 - 6 } & & & 1 & 2 & 3 \\
\hline No Plan Yet & \multirow{2}{*}{1} & 6 & 4 & 2 & 0 \\
Planning & 2 & 22 & 3 & 15 & 4 \\
& & & 13.6 & 68.2 & 18.2 \\
Implemented & 3 & 33 & 0 & 6 & 27 \\
& & & 0 & 18.2 & 81.8 \\
\hline
\end{tabular}

Percentage of "grouped" cases correctly classified: $75.41 \%$ 
Table 7: Hit ratio for cases in the holdout sample

\begin{tabular}{|c|c|c|c|c|c|}
\hline \multirow[t]{2}{*}{$\begin{array}{l}\text { Actual Group } \\
\text { Group }\end{array}$} & \multirow[t]{2}{*}{ Cat. } & \multirow[t]{2}{*}{$\begin{array}{l}\text { N. of } \\
\text { Cases }\end{array}$} & \multicolumn{3}{|c|}{$\begin{array}{l}\text { Predicted } \\
\text { Membership }\end{array}$} \\
\hline & & & 1 & 2 & 3 \\
\hline No Plan Yet & 1 & 1 & 0 & 1 & 0 \\
\hline & & & 0 & 100 & 0 \\
\hline Planning & 2 & 16 & 0 & 12 & 4 \\
\hline & & & 0 & 75 & 25 \\
\hline Implemented & 3 & 7 & $\begin{array}{l}0 \\
0\end{array}$ & 1 & $\begin{array}{r}6 \\
85\end{array}$ \\
\hline
\end{tabular}

Percentage of "grouped" cases correctly classified: $75.00 \%$

Table 8: Comparison of goodness of measure

\begin{tabular}{lcc}
\hline Measure & Value & $\begin{array}{c}\text { Hit Ratio for } \\
\text { Holdout } \\
\text { Sample }\end{array}$ \\
\hline Maximum Chance & $66.60 \%$ & $75.00 \%$ \\
Proportional Chance & $53.12 \%$ & $75.00 \%$ \\
Press Q & 6.635 & \\
Table Value & $18.75^{* *}$ & \\
Calculated Value & & \\
\hline
\end{tabular}

** significant at $\alpha=0.01$

likelihood and proportional chance criterias. Also it is signicant at 0.01 using the Press Q statistics.

Table 9 shows the interpretive measures where the discriminat function loadings, univariate $\mathrm{F}$ ratio and also the potecny index is presented. From the potecy index we can conclude that online competitiveness is ranked the most important followed by value chain management dan customer relationship management in influencing e-commerce initiatives.

Table 9: Summary of interpretive measures for discriminant analysis

\begin{tabular}{lccrr}
\hline $\begin{array}{l}\text { Indep. } \\
\text { Variable }\end{array}$ & $\begin{array}{c}\text { Discriminant } \\
\text { Function } \\
\text { Func- } \\
\text { tion 1 }\end{array}$ & $\begin{array}{c}\text { Loading } \\
\text { Func- } \\
\text { tion 2 }\end{array}$ & $\begin{array}{c}\text { Univariate } \\
\text { F Ratio }\end{array}$ & $\begin{array}{c}\text { Potency } \\
\text { Index }\end{array}$ \\
\hline Online & 0.847 & -0.108 & 29.092 & 0.702 \\
Value & 0.787 & 0.999 & 17.635 & 0.628 \\
Customer & 0.651 & -0.71 & 25.225 & 0.426 \\
\hline
\end{tabular}

\section{DISCUSSION}

This study is an exploratory study in which the researcher is interested in identifying the major factors driving the initiative on e-commerce strategy. This study is also intended to establish if Malaysian companies operating in the FIZ
Penang and Kedah are lagging in initiative in adopting e-commerce compared to foreign companies.

This study found Online Competitiveness, Customer Relationship Management and Value Chain Management are factors significantly affecting e-commerce initiative for manufacturing companies operating in FIZ in the state of Penang and Kedah. This is consistent with opinions of most IT experts in the e-commerce, and may serve as a guideline for other companies in evaluating e-commerce project implementation.

Most companies operating in FIZ Penang and Kedah have been in business for a number of years and they are relatively up to date in IT deployments, the Internet connectivity has provided them an effective medium to enhance their strengths in online competitiveness, customer relationship management and value chain management. These strengths will enable them to operate efficiently and improve their ability to respond to competitive pressures on costs, speed and quality.

Due to geographical reasons and lagging in advanced IT infrastructures and technologies, Malaysia is generally seen as slow in adopting new and enabling technologies. Malaysian companies are expected to fall behind foreign companies in e-commerce initiative in this study. This study found American companies are leading Malaysian companies in e-commerce initiative. However, this study found Malaysian companies on par with European and East Asian companies in e-commerce initiative. The purposive judgmental sampling method employed in this study may also have caused the good rating on Malaysian companies in ecommerce initiative. Records from IT vendors have shown more than $50 \%$ of responding Malaysian companies are well equipped with substantial IT infrastructure setup, e.g. EDI, ERP applications and groupware applications.

Many multinational corporations have been operating in FIZ in Penang for more than 25 years, and most of them frequently imposing requirements for good IT infrastructure setup on their business partners. Over time, these Malaysian companies supporting the multinational corporations have also upgraded their facilities and technology adoption to be on par with their major customers for continuebusinesses. At least three responding Malaysian companies are KLSE listed companies, which are 
well managed, are known to have IT infrastructure and applications on par with other multinational corporations.

\section{IMPLICATION OF FINDINGS}

The findings suggest several general implications. This study enlightens us about Malaysian companies' readiness into ecommerce. Malaysian companies are only lagging behind American companies, but on par with European and East Asian companies in electronic commerce initiative. This is in contrary to general perception that Malaysian companies are lagging in IT implementation. Inline with the $7^{\text {th }}$ Malaysian Plan (The Star, May 7 1996) to help local companies to be IT ready as we are moving towards more open and challenging marketplace in the globalization age, a lot of Malaysian companies may have heed the government's advise and take up the challenge.

Malaysian manufacturing companies, particularly in the small and medium industries operating in Free Industrial Zone in Penang and Kedah, are mostly relying on MNC's for business. They enjoy comparative advantages in lower labor cost, availability of skilled workforce, and government protection from foreign competition. Foreign direct investment in Malaysia has slowed down recently, especially after the Asian financial crisis. Malaysian manufacturing companies need to look into expanding their current market for continued business and future growth. The world is moving into the trade liberalization era, transitioning from GATT to WTO, barrier and control on international trade will be dismantled stage by stage. As we are moving into a bigger and more open economy, American companies with its global presence and size, coupled with its efficiency achieved through effective management, and new and enabling information technology will continue to dominate the world market. Malaysian companies can emulate the American companies in adopting e-commerce strategy to compete more effectively in the globalization age.

In today's 'Networked Economy', where individuals and companies worldwide are being electronically linked, e-commerce will be a norm in time to come. Companies should continue to evaluate effective strategy to maintain international competitiveness. Online competitiveness, customer relationship management and value chain management are important strengths for Malaysian companies to acquire or enhance further to compete effectively in the open global marketplace.

E-commerce is an enabling technology for smaller Malaysian companies to engage in business with their customers worldwide; with informative web site hosted by Internet service providers, they can attain online competitiveness with greater market reaches and well-profiled interactive web site resources enhance customer relationship. Logistics and payment gateways can be managed by established courier service and bank with no start-up cost. This enables smaller companies to compete effectively as other bigger companies which have establishment on sales, marketing, finances and distribution functions in their organizations. Smaller Malaysian companies can concentrate their limited resources into their core competency to develop competitive products and services. Malaysian companies that have not planned or embarked on e-commerce can use this study as a guideline in evaluating their strengths in online competitiveness, customer relationship management and value chain management.

\section{REFERENCES}

Anderson Consulting 1999. "What is eCommerce? eEnterprises conduct eCommerce in the e-Economy" http://www.ac.com/ecommercelecom_what_is.html

Bitner, M. J. 1995. "Building Service Relationships: It's All About Promises," Journal of the Academy of Marketing Science, 23 (4): 246 - 251.

Cisco Connection (http://www.cisco.com)

Cisco Intelligent Network Services: White Paper 1999. http://www.cisco.com/warp/public/ cc/sol/ mkt/ent/ ccn/cins_wp.htm

Electronic Commerce World Institute 1996. "Resource Center Glossary" http:/www.ecworld.org/ Resource Center/Glossary/glossary.html

Ecommerce Resource "The Ecommerce Guide" http:// ecommerce.internet.com/resources/library

Forrester's Leading Internet Research, http://www. forrester.com

Hogg, E. C. A. 1995. "New Link Partner, Everything is Speeding Up," http://www. newlink. on.ca/ wayneb/ n951207.htm

Haynes, T. 1995. "The Electronic Commerce Dictionary," The Robleda Company http:// ecommerce.internet.com/resources/library/

$\mathrm{HP}$ e-servces Centre http://www.hp.com/e-services

Internet Commerce 1999. "Linking Supply Chains for Profit, Oracle Magazine,” 11(3), May/June.

Kalakota, R., and A. B. Whinston. 1996. "Frontiers of Electronic Commerce," Addison-Wesley Publishing Company.

Kosiur, D. 1997. "Understanding Electronic Commerce," Microsoft Press. 
Melnicoff, R. M. 1999. "The e-Economy: It's later than you think," Outlook 1999, 21. http:// www.ac.com/ecommerce

Multiactive Software's e-Builder http://www.ecbuilder. com/ecomnews

Neece, J. 1995. "Caught in the Net of Support," New York Times, Sunday, June 11.

Porter, E. 1994. "Commercialization of the World Wide Web," Internet Conference on WELL, Nov. 161994.

Saia, R. 1999. "Tech Topics are Top CEO Concerns" http://computer.idg.net/crd_it_23506.html

Stone, B. 1994. "Successful Direct Marketing Methods," Lincolnwood, IL: NTC Business Books.

Technology Adoption, Internet Method Consulting 1999. http://www.internetmethods.com/ content/ success_factors.htm

The Star 2000. "Very Good Year: Malaysia notches RM $72 b$ trade surplus for 99" http://www.thestar.com.my /online/newsreport.asp?file $=/ 2000 / 2 / 5 /$ nation/ 0501jasu.asp\&newspage $=$ Search Feb. 5,

The Star 1996. "Nurturing high technology with local touch," The $7^{\text {th }}$ Malaysian Plan, http://thestar.com.my larchives/7mplan/man45.html May 7

Verity, J. W. and J. Carey. 1994. "The Internet: How it will change the way you do business?" Business Week, November.

Wanninger, L. A. 1996. "An Evolutionary Approach to a Revolutionary Set of Business Opportunities," 1st Annual University of Minnesota Conference on Electronic Commerce http://www.iii.csom.umn.edu/ ecconfl

Wanninger, L. A. and D. Bahn. 1996. "Star Tribune Online ${ }^{\mathrm{TM}}$ : A Case Study of a New Venture in the Emerging Information Industry," MISRC Working Paper.

Wanninger, L. A. 1997. "Cheri Anderson, and Robert Hansen, Designing Servicescapes for Electronic Commerce: An Evolutionary Approach," MISRC Working Paper.

Wanninger, L. A. 1997. "A Conceptual Framework for Profitable Electronic Commerce," Carlson School of Management, Minneapolis. 